\title{
Effects of Dietary Mannan Oligosaccharide on Growth Performance, Feed Utilization, Body Composition and Haematological Parameters in Asian Catfish (Clarias batrachus) Juveniles
}

\author{
Mst. Nahid Akter ${ }^{1, *}$ (D), Khurshid Zahan², Md. Abu Zafar ${ }^{1}$, Najida Khatun ${ }^{2}$, Md. Sohel \\ Rana², Md. Imamul Mursalin²
}

\begin{abstract}
${ }^{1}$ Hajee Mohammad Danesh Science and Technology University, Faculty of Fisheries, Department of Aquaculture, Dinajpur 5200, Bangladesh.

${ }^{2}$ Hajee Mohammad Danesh Science and Technology University, Department of Aquaculture, MS student, Dinajpur 5200, Bangladesh.
\end{abstract}

\section{How to cite}

Akter, M.N., Zahan, K., Zafar, M.A., Khatun, N., Rana, M.S., Mursalin, M.I. (2021). Effects of Dietary Mannan Oligosaccharide on Growth Performance, Feed Utilization, Body Composition and Haematological Parameters in Asian Catfish (Clarias batrachus) Juveniles. Turkish Journal of Fisheries and Aquatic Sciences, 21, 559-567. http://doi.org/10.4194/1303-2712-v21_11_04

\section{Article History}

Received 29 December 2019

Accepted 14 July 2021

First Online 14 July 2021

\section{Corresponding Author}

Tel.: +8801717526074

E-mail: mstnahidakter@gmail.com

\section{Keywords}

Growth and survival

Body indices

Health status

Clarias batrachus

Prebiotic

\begin{abstract}
The influence of dietary supplementation of mannan oligosaccharide (MOS) on growth performance, feed utilization, body composition and haematological parameters were evaluated in Asian catfish (Clarias batrachus) juveniles. Triplicate groups of juveniles Asian catfish $(21.23 \pm 1.01 \mathrm{~g})$ were fed twice per day at $3 \%$ of body weight for 12 weeks, with 0 (control), $0.2,0.4$ or $0.6 \%$ MOS diets. Compared to control, those fed with MOS supplemented diets had significantly improved $(\mathrm{P}<0.05)$ specific growth rates, protein efficiency ratio and survival rate. Significantly lower hepatosomatic index was noted in $0.2 \%$ and $0.4 \%$ MOS diets compared to those fish fed control. Similarly, intraperitoneal fat was significantly lowest in those fish fed with $0.4 \%$ diet over the control group. The highest protein content was $(81.86 \pm 0.36)$ in fish fed with $0.4 \%$ MOS diet, whereas ash content was highest $(7.33 \pm 1.23)$ in fish group fed with $0.6 \%$ MOS. Significantly decreased erythrocyte sedimentation rate and increased packed cell volume were observed when the fish fed with $0.4 \%$ and $0.6 \%$ MOS diets compared to the remaining treatments. MOS supplemented diets showed significant influence on the white blood cell count compared to the control. Thus, $0.4 \% \mathrm{MOS}$ is sufficient to improve growth and haematological parameters in Asian catfish.
\end{abstract}

\section{Introduction}

Aquaculture systems practiced all over the world have been intensified dramatically due to fulfil the protein demand for the over growing population's. Rapid intensification and disease resistance of pathogenic microorganisms are the major concerns of this growing aqua food producing sector (Genc et al., 2007). To address these obstacles, for the last decades antibiotics have been widely used in animal feeds as a therapeutic agent for fish disease management (Denev et al., 2009) but the indiscriminate use of antibiotic has led to increase of antibiotic resistant bacteria and destruction of environmentally friendly microbial flora (Yousefian \& Amiri, 2009) and reduced immune response (Ringo et al., 2010). Even though the probiotic bacteria are now gradually used in aquaculture to overcome antibiotic induced disease resistance and growth of farmed fish (Verschuere et al., 2000). However, the large-scale use of probiotics in commercial aquaculture has been limited due to problems associated with handling, pelleting and storage (Merrifield et al., 2010). A new effective approach to overcome issues associated with antibiotic and probiotic 
applications in aquaculture is the use of prebiotics. Prebiotics which are defined as non-digestible food ingredients positively affect the host by stimulating growth and/or activity of a limited number of beneficial bacteria in the gastrointestinal tract and have showed to be effective at improving health and growth performance of terrestrial and aquatic animals (Gibson \& Roberfroid, 1995). Among the recognized prebiotics, mannan oligosaccharide (MOS) is most commonly used as the dietary supplementation for fish and crustacean species (Sang \& Fotedar, 2010). MOS are glucomannoprotein complexes derived from the cell wall of yeast (Saccharomyces cerevisiae) (Sang \& Fotedar, 2010). MOS has been shown to act as receptor analogues to Type-1 fimbrial adhesins of pathogenic bacteria, preventing them from colonizing in the gastrointestinal tract and ultimately resulting in its excretion from the intestinal tract (Pryor et al., 2003). In this way, MOS not only prevents gastrointestinal attachment of these pathogenic bacteria, but also it removes the attached pathogens (Newman, 1994) from the gastrointestinal tract. The use of functional feed additives such as MOS to increase growth and health performance in the aquaculture industry is increasingly significant as which are required for the eco-friendly production practices (Dimitroglou et al., 2009). A comparatively simple culture characteristic with effective food conversion (Ali \& Jauncey, 2005) and excellent nutritional profile (Rosa et al., 2007) makes Clarias particularly C. batrachus very suitable for commercial intensive culture. Intensive $C$. batrachus culture in the rural areas of Bangladesh has much potential towards livelihood development, employment generation and ensuring nutritional enhancement in the regular diet among all the people.

In contrast to the progress made in other species, MOS effects on Asian catfish have received little attention. Therefore, this study was initiated to determine the optimal inclusion level of MOS with feed ingredients for optimum growth performance, feed utilization parameters, body composition and hematological parameters of $C$. batrachus juveniles.

\section{Materials and Methods}

\section{Experimental Site}

The feeding trial was conducted at the hatchery complex of Caritas, Bochagonj, Dinajpur, Bangladesh. Twelve cemented tanks measuring $(200 \mathrm{~cm} \times 100 \mathrm{~cm} \times$ $100 \mathrm{~cm}$ ) were used for this study under controlled conditions. Throughout the experiment, water was supplied from an overhead tank.

\section{Experimental Design and Feeding Trial}

Asian catfish (average weight $15 \pm 1.00 \mathrm{~g}$ ) were procured from a hatchery in Dinajpur, Bangladesh, and were transported in oxygenated plastic bags filled with freshwater. The fish were acclimatized for two weeks prior to the commencement of the study and were fed to apparent satiation with a commercial feed. Thereafter, the fish (average body weight $21.23 \pm 1.01$ g) were randomly distributed into twelve cemented tank with a stocking density of 20 fish per tank. Three replicate tanks for each treatment were established. The fish were fed with the respective experimental diets at a rate of $3 \%$ body weight. The daily ration was presented in equal portions at 09:00 and 5:00 for a period of 12 weeks. Faeces were regularly siphoned out. Tanks were cleaned fortnightly to reduce the risk of accumulation of nitrogenous waste.

\section{Diet Preparation}

Four experimental diets were formulated to contain MOS 0 (control), $0.2,0.4$, and $0.6 \% \mathrm{MOS}$ (International Food Grade, Lab. USA, Purity > 90\%). The doses of MOS were carefully chosen based on the previous studies (Torrecillas et al.,2011; Do Huu \& Jones, 2014). Fishmeal and soybean meal were used as main protein sources, soybean and fish oils as lipid sources, corn starch and wheat flour as carbohydrate sources to ensure similar energy levels in the experimental diets (Phumee, 2011). Diets were prepared by thoroughly mixing feed ingredients (Table 1) for 30 minutes in a food mixer at a capacity of $5 \mathrm{~kg}$. After addition of soybean oils and fish oil, the feed ingredients were mixed for an extra 10 minutes (Salaghi et al., 2013). Sufficient water was added to make dough which was then extruded through a pelletizing machine to make 3 $\mathrm{mm}$ diameter pellets, air dried for 24 hours, and then manually broken into smaller pieces. The resultant pellets were packed separately in plastic bags and stored in a freezer at $-20^{\circ} \mathrm{C}$ throughout the feeding trial.

\section{Sampling Procedure}

The fish survival was recorded throughout the feeding trial. In each group, individual fish weight was measured at the start and end of the experiment, but the bulk weight was measured fortnightly to monitor the somatic growth and to adjust the amount of feed to be given. After a twelve week feeding trial, all of the experimental fish were starved for approximately 24 hours, and three fish were then randomly selected from each replicate tank (nine fish per treatment) for the determination of body proximate composition (AOAC, 1997) and body indices. The selected fish were killed by keeping them in ice-cold distilled water. After being killed, fish were weighed immediately and kept in a freezer at $-20^{\circ} \mathrm{C}$ until the time of use. Whole fish body, liver, intraperitoneal fat and viscera weight were recorded individually (nine fish per treatment) at the end of the feeding trial for the determination of body index parameters, such as hepatosomatic index (HSI), intraperitoneal fat (IPF) and viscerosomatic index (VSI). 
Table 1. Ingredients used of the experimental diets containing varying levels of mannan oligosaccharide (MOS) $\left(\mathrm{g} \mathrm{kg}^{-1}\right)$

\begin{tabular}{lcccc}
\hline \multirow{2}{*}{ Ingredients } & \multicolumn{3}{c}{ Treatments } \\
\cline { 2 - 5 } & Control & $0.2 \%$ MOS & $0.4 \%$ MOS & $0.6 \%$ MOS \\
\hline Fish meal $^{1}$ & 247 & 247 & 247 & 247 \\
Soybean meal & 280 & 280 & 280 & 280 \\
Corn starch & 97.5 & 97.5 & 97.5 & 97.5 \\
Wheat floor & 270 & 268 & 266 & 264 \\
Soybean oil & 32.6 & 32.6 & 32.6 & 32.6 \\
Fish oil & 32.6 & 32.6 & 32.6 & 32.6 \\
vitamin mix & 20 & 20 & 20 & 20 \\
mineral mix & 20 & 20 & 20 & 20 \\
MOS & 0 & 2 & 4 & 6 \\
\hline
\end{tabular}

${ }^{1}$ Danish fishmeal: crude protein, 720; crude lipid, 50.

${ }^{2}$ Vitamin mix kg-1 (Rovithai Ltd 700/437 Chonburi THAILAND): A 50 MIU, D 10 MIU, E 130g, K 3 10g, B 1 10g, B 25g, B 6 16g, B 12 100mg, Niacin 200g, pantothenic acid $56 \mathrm{~g}$, folic acid $8 \mathrm{~g}$, Biotin $500 \mathrm{mg}$, antioxidant $0.200 \mathrm{~g}$ and anticake $20 \mathrm{~g}$.

${ }^{3}$ Mineral mix kg-1: Calcium phosphate (monobasic) $397.5 \mathrm{~g}$; calcium lactate $327 \mathrm{~g}$; Ferrous sulphate $25 \mathrm{~g}$; Magnesium sulphate $137 \mathrm{~g}$; Potassium chloride, 50 g; Sodium chloride, 60 g; Potassium iodide, 150 mg; Copper sulphate 780 mg; Manganese oxide $800 \mathrm{mg}$; Cobalt carbonate $100 \mathrm{mg}$; Zinc oxide $1.5 \mathrm{~g}$ and Sodium selenite $20 \mathrm{mg}$.

\section{Water Quality Parameters}

Temperature, dissolved oxygen (DO), $\mathrm{pH}$ and ammonia were measured fortnightly. Temperature was recorded using a standard mercury thermometer, DO by a digital DO 5509 meter and pH and ammonia using a commercial test kit.

\section{Growth Performance and Body Indices Parameters}

The following growth parameters were observed such as:

Weight gain $(W G)=$ final body weight $(g)$ - initial body weight (g);

Specific growth rate (SGR \%/day) $=100 \times($ In FW [g] - In initial weight $[\mathrm{g}] /$ days of the trial); Feed conversion ratio $(F C R)=$ feed intake $(\mathrm{g}) / \mathrm{WG}(\mathrm{g})$;

Protein efficiency ratio $(P E R)=W G(g) /$ protein intake (g) and

Survival rate $(\%)=($ final number of fish $/$ initial number of fish) $\times 100$

At the end of the experiment, body indices of Asian catfish such as hepatosomatic index (HSI), intraperitoneal fat (IPF) and viscerosomatic index (VSI) were determined by using the following formulae as previously used by Akter et al. (2019):

Hepatosomatic index $(\mathrm{HSI})=\frac{\text { Liver weight }(\mathrm{g})}{\text { Body weight }(\mathrm{g})} \times 100$

$$
\mathrm{IFP} \%=\frac{\text { Intraperitoneal fat weight }(\mathrm{g})}{\text { Body weight }(\mathrm{g})} \times 100
$$

IFP: Intraperitoneal fat

$$
\text { VSI } \%=\frac{\text { Viscera weight }(\mathrm{g})}{\text { Body weight gain }(\mathrm{g})} \times 100
$$

\section{Proximate Composition Analysis}

At the end of the experiment, whole body proximate composition of Asian catfish was determined by using the standard protocols as mentioned by the Association of Official Analytical Chemists (AOAC, 1997). Moisture content was evaluated by drying the samples in the Hot Air Oven at $105^{\circ} \mathrm{C}$ for 12 hours. Crude protein content was calculated indirectly by determining the total nitrogen of the fish sample by a Kjeldahl method using kjeldhal apparatus. The crude lipid content of the samples was determined by removing the lipid from the samples by homogenizing it in $60 \mathrm{ml}$ of chloroform and methanol solution in a ratio of 2:1 ( $\backslash \mathrm{v}$ ) (Folch et al., 1957) and thereafter the solvent was evaporated by heating in the oven at $80^{\circ} \mathrm{C}$. Finally, the ash content was measured by igniting the samples in a muffle furnace at a temperature of $550{ }^{\circ} \mathrm{C}$ for 6 hours.

\section{Haematological Analysis}

In order to determine the haematological parameters, the experimental fish were starved for 24 hours and then six fish per treatment ( 2 fish per replicate tank) were randomly selected and immediately stabilized to reduce stress during handling. The collection of blood was carried out by inserting a 21gauge needle attached to a $1 \mathrm{ml}$ syringe into the muscle at the end of the anal fin until it reached the backbone. The collected blood was then transferred to a heparinized tube to prevent the blood clotting for determining the erythrocyte sedimentation rate (ESR), packed cell volume (PCV), red blood cells (RBC), hemoglobin $(\mathrm{Hb})$, white blood cells (WBC) and red blood cell indices such as mean corpuscular hemoglobin concentration (MCHC), mean corpuscular hemoglobin $(\mathrm{MCH})$ and mean corpuscular volume (MCV) as previously described by Akter et al. (2019). 


\section{Statistical Analysis}

The results were analyzed statistically using oneway analysis of variance (ANOVA) and the mean differences among the four different treatments were tested with a significance level of $\mathrm{P}<0.05$ using a Duncan's multiple range test (Duncan, 1955). All statistical analyses were computed using SPSS software, version 22 for Windows. The data were presented as mean \pm Standard deviation (SD).

\section{Results}

\section{Water Quality Parameters}

Water temperature, $\mathrm{pH}$, dissolved oxygen, $\mathrm{NH}_{4}{ }^{+}$ and $\mathrm{NH}_{3}$ were monitored in every two weeks for a 12 weeks period, which were ranged between 17.66$18.42^{\circ} \mathrm{C}, 7.06-7.22,5.06-6.13 \mathrm{mg} \mathrm{L}^{-1}, 0.49-0.61 \mathrm{mg} \mathrm{L}^{-1}$ and $0.34-0.48 \mathrm{mg} \mathrm{L}^{-1}$ respectively (Table 2 ).

\section{Growth Performance and Body Indices}

Growth performance, survival and body indices of Asian catfish juveniles fed with varying levels of MOS diets for 12-week are presented in Table 3. Generally, growth performance, such as weight gain and SGR were dose dependent and significantly enhanced $(P<0.05)$ in fish fed $0.4 \%(21.21 \pm 1.16 ; 0.82 \pm 0.05)$ and $0.6 \%$ $(18.66 \pm 0.96 ; 0.77 \pm 0.04)$ MOS diets over the control $(12.94 \pm 0.88 ; \quad 0.57 \pm 0.04)$ fed group. The supplementation of MOS at $0.4 \%$ significantly influenced $(P<0.05)$ the feed utilization parameters such as FCR and PER compared to those fish that were fed with control and $0.2 \%$ MOS diets and which was not significant when compared with $0.6 \%$ MOS diet fed group.

The survival rate of Asian catfish fed with the control diet presented significantly lowest $(P<0.05)$ when compared with the fish fed with MOS supplemented diets. With the exclusion of VSI, a significant variation was detected in HSI and IPF in fish fed the MOS supplemented diets. Significantly lower $(\mathrm{P}<0.05) \mathrm{HSI}$ was prominent when fish fed 0.2 and $0.4 \%$ MOS diets compared to those fish fed with control diet, but it did not differ from those fish fed with $0.6 \%$ MOS diet. Similarly, IPF was significantly lowest $(P<0.05)$ in those fish which fed $0.4 \%$ diets over the control fed group.

\section{Whole Body Proximate Composition}

Proximate composition of whole body of Asian catfish fed with various concentrations of MOS is shown in Table 4. Significantly higher $(P<0.05)$ body protein content was detected in fish treated with $0.4 \%$ MOS diet $(81.86 \pm 0.36)$ compared to the control group (78.32 \pm 0.36$)$. Whereas, significantly lower $(P<0.05)$ lipid content was also detected in fish fed $0.4 \% \mathrm{MOS}$ diet when compared to fish that were fed a higher MOS diet at $0.6 \%$ and the control. Ash content was significantly highest $(P<0.05)$ in fish fed on $0.6 \%$ MOS related to those fish that were fed with control diet.

Table 2. Water quality parameters of the experimental tanks

\begin{tabular}{|c|c|c|c|c|}
\hline \multirow{2}{*}{ Parameters } & \multicolumn{4}{|c|}{ Treatments } \\
\hline & Control & $0.2 \% \mathrm{MOS}$ & $0.4 \% \mathrm{MOS}$ & $0.6 \% \mathrm{MOS}$ \\
\hline Temperature ${ }^{\circ} \mathrm{C}$ & $17.92 \pm 0.09$ & $18.23 \pm 0.10$ & $18.42 \pm 1.04$ & $17.66 \pm 0.36$ \\
\hline $\mathrm{pH}$ & $7.12 \pm 0.11$ & $7.06 \pm 0.03$ & $7.11 \pm 0.04$ & $7.22 \pm 0.08$ \\
\hline Dissolved oxygen $\left(\mathrm{mgL}^{-1}\right)$ & $5.06 \pm 0.26$ & $5.87 \pm 0.10$ & $5.60 \pm 0.57$ & $6.13 \pm 0.20$ \\
\hline $\mathrm{NH}_{4}{ }^{+}\left(\mathrm{mgL}^{-1}\right)$ & $0.49 \pm 0.17$ & $0.61 \pm 0.17$ & $0.56 \pm 0.29$ & $0.60 \pm 0.12$ \\
\hline $\mathrm{NH}_{3}\left(\mathrm{mgL}^{-1}\right)$ & $0.45 \pm 0.16$ & $0.46 \pm 0.06$ & $0.34 \pm 0.35$ & $0.48 \pm 0.24$ \\
\hline
\end{tabular}

Table 3. Growth performance, feed utilization and body indices of juvenile Asian catfish, Clarias batrachus, fed a diet containing varying levels of mannan oligosaccharide (MOS) for 12 weeks.

\begin{tabular}{|c|c|c|c|c|}
\hline \multirow{2}{*}{ Parameters } & \multicolumn{4}{|c|}{ Treatments } \\
\hline & Control & $0.2 \% \mathrm{MOS}$ & $0.4 \% \mathrm{MOS}$ & $0.6 \% \mathrm{MOS}$ \\
\hline Initial av. wt. & $21.01 \pm 0.54$ & $21.60 \pm 0.55$ & $21.61 \pm 0.82$ & $20.68 \pm 0.56$ \\
\hline Final av. wt. & $33.95 \pm 0.40^{a}$ & $38.48 \pm 0.75^{b}$ & $42.82 \pm 1.00^{c}$ & $39.34 \pm 0.73^{b}$ \\
\hline wt. gain & $12.94 \pm 0.88^{a}$ & $16.88 \pm 1.16^{b}$ & $21.21 \pm 1.16^{c}$ & $18.66 \pm 0.96^{b c}$ \\
\hline SGR (\%) & $0.57 \pm 0.04^{a}$ & $0.69 \pm 0.05^{\mathrm{ab}}$ & $0.82 \pm 0.05^{b}$ & $0.77 \pm 0.04^{b}$ \\
\hline FCR & $4.71 \pm 0.28^{d}$ & $2.79 \pm 0.35^{b}$ & $1.92 \pm 0.15^{\mathrm{a}}$ & $2.16 \pm 0.08^{a b}$ \\
\hline PER & $0.59 \pm 0.03^{a}$ & $1.02 \pm 0.14^{\mathrm{b}}$ & $1.45 \pm 0.12^{c}$ & $1.27 \pm 0.05^{b c}$ \\
\hline Survival rate (\%) & $86.67 \pm 1.67^{a}$ & $95.00 \pm 2.89^{\mathrm{b}}$ & $100 \pm 0.0^{\mathrm{b}}$ & $98.33 \pm 1.67^{b}$ \\
\hline HSI (\%) & $0.75 \pm 0.08^{b}$ & $0.54 \pm 0.08^{a}$ & $0.42 \pm 0.02^{a}$ & $0.62 \pm 0.07^{a b}$ \\
\hline IPF (\%) & $0.55 \pm 0.04^{b}$ & $0.43 \pm 0.08^{a b}$ & $0.37 \pm 0.02^{a}$ & $0.44 \pm 0.02^{\mathrm{ab}}$ \\
\hline VSI (\%) & $3.73 \pm 0.39$ & $3.41 \pm 0.42$ & $3.56 \pm 0.10$ & $3.65 \pm 0.22$ \\
\hline
\end{tabular}

All values are presented as Mean \pm Standard Deviation obtained from three replicates tank, $(n=3)$; Data with different superscripts in the same row indicate significant differences $(\mathrm{P}<0.05)$; SGR, specific growth rate; FCR, food conversion ratio; PER, protein efficiency ratio; HSI, hepatosomatic index: IPF. Intraperitoneal fat: VSI, viscerosomatic index: MOS, mannan oligosaccharide. 
Table 4. Proximate composition of whole body of juvenile Asian catfish, (Clarias batrachus), fed varying levels of MOS for 12 weeks (\% dry matter basis)

\begin{tabular}{lccc}
\hline \multirow{2}{*}{ Treatments } & \multicolumn{3}{c}{ Parameters } \\
\cline { 2 - 5 } & Protein (\%) & Lipid (\%) & $10.62 \pm 1.57^{\mathrm{bc}}$ \\
$0.2 \%$ MOS & $78.32 \pm 0.36^{\mathrm{a}}$ & $8.96 \pm 1.0^{\mathrm{ab}}$ & $5.06 \pm 1.08^{\mathrm{a}}$ \\
$0.4 \%$ MOS & $80.31 \pm 1.41^{\mathrm{ab}}$ & $8.62 \pm 0.56^{\mathrm{a}}$ & $5.77 \pm 0.07^{\mathrm{ab}}$ \\
$0.6 \%$ MOS & $81.86 \pm 0.36^{\mathrm{b}}$ & $11.87 \pm 0.73^{\mathrm{c}}$ & $6.32 \pm 1.04^{\mathrm{ab}}$ \\
\hline
\end{tabular}

Data presented as Mean \pm Standard Deviation, $(n=9,3$ fish per replicate tank). Data with different superscripts in the same column indicate significant differences $(P<0.05)$.

\section{Haematological Parameters}

The influence of dietary MOS supplementation on Asian catfish blood profile is presented in Table 5 . Among RBC and interrelated haematological parameters only ESR and PCV were significantly influenced by the feeding of MOS supplemented diets. Significantly reduced $(\mathrm{P}<0.05)$ ESR was prominent when the fish fed with higher concentration of $\operatorname{MOS}(0.4 \%$ and $0.6 \% \mathrm{MOS}$ ) diets compared to those fish that were fed with control and lowest concentration of MOS such as $0.2 \%$. PCV significantly increased $(P<0.05)$ when fish fed with the $0.4 \%$ and $0.6 \%$ MOS diets compared to the control and $0.2 \%$ MOS diet fed fish. A non-significant increase $(P>0.05)$ of $R B C$ and $\mathrm{Hb}$ content were found when juvenile Asian catfish fed with MOS supplemented diets. Feeding fish with MOS supplemented diets showed significant influence $(P<0.05)$ on the WBC compared with the control diet.

\section{Glucose Content of Blood}

The influence of dietary MOS supplementation on Asian catfish blood glucose content is shown in Figure 1. The blood glucose content results exposed that the highest concentration of blood glucose was detected in the blood of Asian catfish fed with highest concentration $(0.6 \%)$ of MOS which was not vary significantly fed with $0.4 \%$ MOS diet.

\section{Discussion}

Mannan oligosaccharide is derivative from the cell walls of the yeast Saccharomyces cerevisiae and is used as a dietary supplement in aquaculture (Wu et al., 2014) because of its capability to improve growth, survival and immune-modulation functions (Staykov et al., 2007; Torrecillas et al., 2007, 2011; Sang \& Fotedar, 2010). The current research is the first time attempt to demonstrate the effectiveness of MOS on the enhancement of growth and survival of juvenile Asian catfish. In the current study the higher MOS concentration at $0.4 \%$ have positive influence on the growth performance of Asian catfish. In contrast, $0.2 \%$ MOS was sufficient to improve the growth performance of yellow catfish (Pelteobagrus fulvidraco) (Wu et al., 2014), whereas, $0.3 \%$ MOS showed better growth in the case of crayfish (Mazlum et al., 2011). Similar to the present study, MOS supplementation improved growth performance of rainbow trout (Staykov et al., 2007), green tiger prawn (Genc et al., 2007), European sea bass (Torrecillas et al., 2007), Nile tilapia (Samrongpan et al., 2008), tropical juvenile spiny lobster (Sang \& Fotedar, 2010), freshwater crayfish (Mazlum et al., 2011), gilthead sea bream (Gültepe et al., 2011), rainbow trout (Denji et al., 2015), Asian sea bass (Ali et al, 2017); however, this was not found in the Gulf of Mexico sturgeon (Pryor et al., 2003), channel catfish (Welker et al., 2007), Nile tilapia (Sado et al., 2008), Atlantic salmon (Grisdale-Helland et al., 2008), gilthead sea bream (Dimitroglou et al., 2010), channel catfish (Peterson et al., 2012) or giant sturgeon (Mansour et al., 2012). The reasons for the different results are not clearly understood. Previous research reported that prebiotics particularly MOS can utilize varying responses in fish based on the basal diet consumed, inclusion level, source and purity of MOS, processing methods used in their manufacture, acclimation and culture period, animal characteristics (species, age, source), and hygienic conditions of the experiment (Pryor et al., 2003; Reza et al., 2009; Gültepe et al., 2011; Taati et al., 2011).

The body proximate composition of $C$. batrachus juveniles were significantly influenced after feeding MOS supplemented diets, which was not found in Atlantic salmon (Grisdale-Helland et al., 2008); rainbow trout and common carp (Dimitroglou et al., 2011); Asian seabass (Ali et al., 2017) and grey mullet (Akbary et al., 2018). Similar to the present study, $0.4 \%$ MOS supplementation was shown to increase body protein content in Atlantic Salmon Smolts (Salmo salar) (Dimitroglou et al., 2011) and rainbow trout (Denji et al., 2015). On the other hand, MOS supplementation showed to improve growth performance in gilthead sea bream but the body proximate composition remains unaffected (Dimitroglou et al., 2010; Gultepe et al., 2011).

As the physiological status of animals is greatly influenced by the existence, and proportion of blood circulating cells, currently, an increasing trend is noticeable in evaluating the haematological parameters as an indicator for identifying the stress responses to endogenous or exogenous changes in fish (Cataldi et al., 1998). The fish is poikilothermic animal; therefore, the haematological parameters can be easily influenced by the environmental factors. Beside this, a range of other 
Table 5. Haematological parameters of juvenile Asian catfish, Clarias batrachus, fed diets containing varying levels of MOS and control diet for 12 weeks

\begin{tabular}{lcccc}
\hline \multirow{2}{*}{ Haematological parameters } & \multicolumn{4}{c}{ Treatment } \\
\cline { 2 - 5 } & Control & $0.2 \% \mathrm{MOS}$ & $0.4 \% \mathrm{MOS}$ & $0.6 \% \mathrm{MOS}$ \\
\hline ESR $\left(\mathrm{mm} \mathrm{h}^{-1}\right)$ & $1.23 \pm 0.08^{\mathrm{b}}$ & $1.38 \pm 0.06^{\mathrm{b}}$ & $0.65 \pm 0.08^{\mathrm{a}}$ & $0.73 \pm 0.09^{\mathrm{a}}$ \\
PCV $(\%)$ & $34.50 \pm 0.56^{\mathrm{a}}$ & $36.50 \pm 0.67^{\mathrm{a}}$ & $38.83 \pm 0.79^{\mathrm{b}}$ & $39.00 \pm 0.77^{\mathrm{b}}$ \\
RBC $\left(\mathrm{x} 10^{6} \mathrm{~mm}^{-3}\right)$ & $3.97 \pm 0.14$ & $4.13 \pm 0.26$ & $4.15 \pm 0.09$ & $4.34 \pm 0.10$ \\
$\mathrm{Hb}\left(\mathrm{gdL}^{-1}\right)$ & $5.63 \pm 0.20$ & $5.72 \pm 0.18$ & $5.73 \pm 0.04$ & $5.81 \pm 0.0 .27$ \\
MCHC $\left(\mathrm{gdL}^{-1}\right)$ & $16.33 \pm 0.63$ & $15.63 \pm 0.61$ & $14.81 \pm 0.34$ & $14.90 \pm 0.73$ \\
MCH $\left(\mathrm{pg} \mathrm{cell}^{-1}\right)$ & $14.22 \pm 0.47$ & $14.24 \pm 1.32$ & $13.84 \pm 0.31$ & $13.41 \pm 0.70$ \\
MCV $\left(\mu \mathrm{m}^{3}\right)$ & $87.71 \pm 4.47$ & $90.70 \pm 6.48$ & $93.83 \pm 3.71$ & $90.14 \pm 2.76$ \\
WBC $\left(\times 10^{4} \mathrm{~mm}^{-3}\right)$ & $4.52 \pm 0.23^{\mathrm{a}}$ & $5.97 \pm 0.18^{\mathrm{b}}$ & $6.25 \pm 0.0 .32^{\mathrm{b}}$ & $5.88 \pm 0.28^{\mathrm{b}}$ \\
\hline
\end{tabular}

Data presented as Mean \pm Standard Deviation, ( $n=6 ; 2$ fish per replicate tank). Data with different superscripts in the same row indicate significant differences $(\mathrm{P}<0.05)$. Erythrocyte sedimentation rate $(\mathrm{ESR})$; packed cell volume $(\mathrm{PCV})$; red blood cells $(\mathrm{RBC})$; hemoglobin ( $\mathrm{Hb})$; white blood cells (WBC); mean corpuscular hemoglobin concentration (MCHC); mean corpuscular hemoglobin (MCH); mean corpuscular volume (MCV).

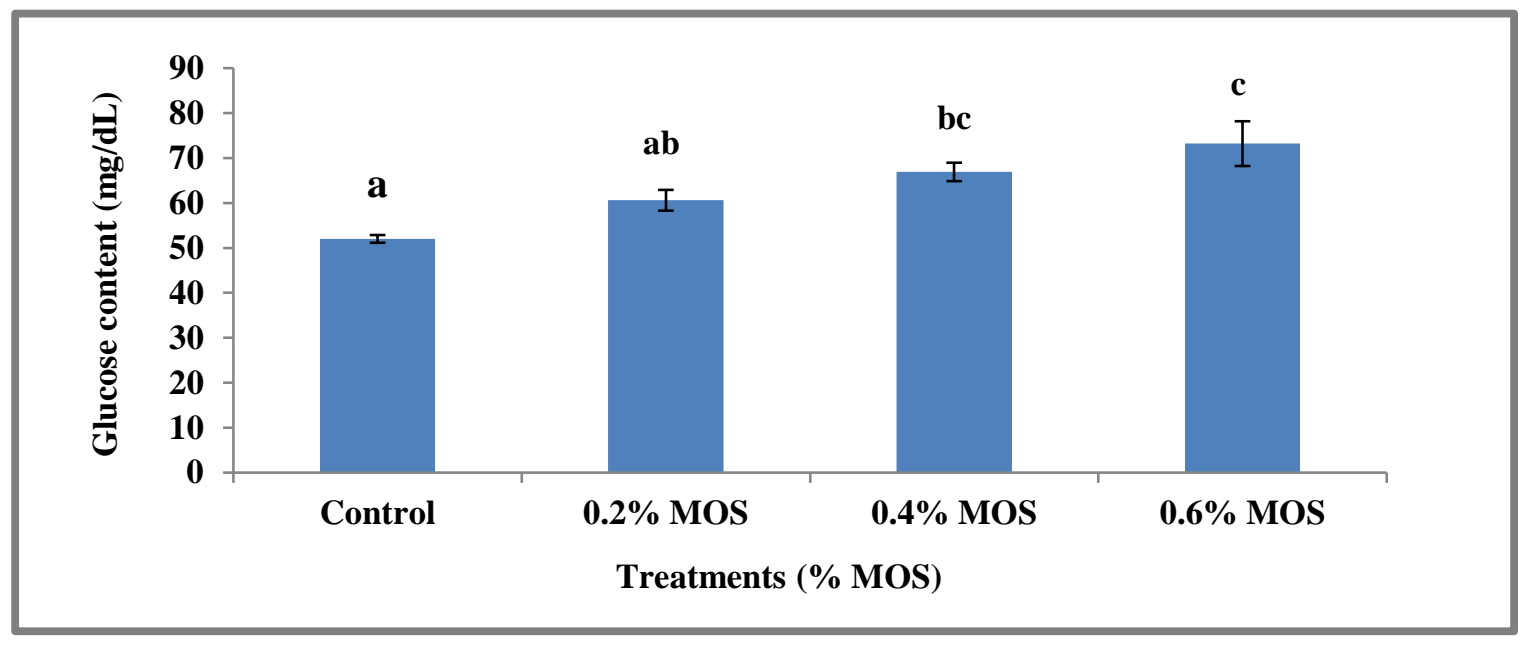

Figure 1. The glucose content of juvenile Asian catfish, Clarias batrachus, after 12 weeks of feeding with 0 (control), $0.2 \%, 0.4 \%$ and $0.6 \%$ MOS (Mannan oligosaccharide). Bars with different letter indicate significantly different $(P<0.05)$. Data presented as Mean \pm Standard Deviation ( $n=6 ; 2$ fish per replicate tank).

factors, including fish species, age, size, physiological conditions and dietary regime (such as quantity and quality of food, ingredients of diet, and sources of protein) have great influence on the haematological parameters of fish (Lim et al., 2000; Irianto \& Austin, 2002).

In the current study, the outcome of most of the haematological parameters including $\mathrm{RBC}, \mathrm{Hb}, \mathrm{MCHC}$, $\mathrm{MCH}$ and $\mathrm{MCV}$ were not significantly $(\mathrm{P}>0.05)$ influenced by the intake of MOS diets in fish groups compared with the control diet. Similarly, many studies also stated that dietary MOS had no effect on haematological parameters of channel catfish (Ictalurus punctatus) (Welker et al., 2007); Nile tilapia (Oreochromis niloticus) (Sado et al., 2008); giant sturgeon (Huso huso) (Mansour et al., 2012); gilthead sea bream (Sparus auratus) (Gultepe et al., 2011; Gelibolu et al., 2018)), rainbow trout (Denji et al, 2015) and Asian seabass (Ali et al., 2017) Significantly lower ESR and higher PCV were observed in Asian catfish fed with $0.4 \%$ and $0.6 \%$ MOS diets compared to the control and $0.2 \%$ MOS fed groups. Similarly, significantly increased PCV was also reported in carp juvenile (Cyprinus carpio) fed with a lower (0.1\%)
MOS level (Akrami et al., 2012). The significantly improved PCV indicates that MOS is safe for consumption and their effectiveness in improving health status, as a lower PCV is an indicator of unhealthy fish as a result of not eating properly or suffering infections (Blaxhall, 1972).

However, the MOS supplementation showed a significant influence on the total WBC count compared with those fish fed with the control diet, which was also reported in Labeo rohita fed with 1\% MOS diet (Andrews et al., 2009). These results indicate that the immune response of Asian catfish was activated by the feeding of the MOS-supplemented diets since WBC play an important role in non-specific immunity or innate immunity, and is being considered as an indicator of good health status of fish (Roberts, 1978).

A non-significantly increasing trend of RBC and $\mathrm{Hb}$ content were noted with the increasing levels of MOS supplemented diets. Increased $\mathrm{Hb}$ content in the blood of Asian catfish also indicated improved health status as it directly linked to increase $\mathrm{O}_{2}$ level in the blood. However, in the present study, the blood glucose content results showed that the highest concentration 
was observed in the blood of Asian catfish fed with $0.6 \%$ of MOS which did not differ significantly with $0.4 \%$ MOS diet. In line with the present study, MOS supplementation up to $2 \%$ showed significant increase in blood glucose content in Asian saebass (Ali et. al, 2017). On the other hand, dietary MOS had no influence on the glucose content of great sturgeon (Akrami et al., 2013); rainbow trout (Denji et al., 2015) and Gilthead Sea Bream (Gelibolu et al., 2018).

\section{Conclusion}

In conclusion, it is evident from the results that the growth performance of the Asian catfish juveniles responded positively to MOS in a dose-dependent manner. Dietary supplementation of MOS at $0.4 \%$ appears to be most effective dose in influencing the growth performance, feed utilization, survival, body proximate composition and haematological parameters of Asian catfish juveniles. Therefore, dietary supplementation of MOS at $0.4 \%$ concentration can be effectively used as a feed additive for improving the growth performance and non-specific immune response of Asian catfish (C. batrachus) juvenile's.

\section{Ethical Statement}

Not Applicable.

\section{Funding Information}

This work was supported by a grant of Bangladesh University Grant Commission (No. 6(78)/Bimok/Biopro/Agri(Life-24)/2016/4368.

\section{Author Contribution}

MNA: Oversight and leadership responsibility for the research activity planning and execution, including mentorship, manuscript editing. KZ: Conduct the experiment, data collection and analysis. MAZ: MS cosupervisor, helped in experimental design, data analysis, manuscript editing. NK: Helped in conducting the experiment, data collection and analysis.MSR: Helped in conducting the experiment, data collection and analysis. MIM: Helped in conducting the experiment, data collection and analysis.

\section{Conflict of Interest}

Authors declare that there is no conflict of interest.

\section{Acknowledgements}

The authors would like to express their sincere appreciation to the authority of the hatchery complex of Caritas, Bochagonj, Dinajpur and University Grant Commission (UGC) for assisting this research.

\section{References}

Akbary, P., \& Jahanbakhshi, A. (2018). Growth yield, survival, carcass quality, haematological, biochemical parameters and innate immune responses in the grey mullet ( $M$. cephalus Linneaus, 1758) fingerling induced by Immunogen ${ }^{\circledast}$ prebiotic. Journal of Applied Animal Research, 46(1), 10-16. https://doi.org/10.1080 / 09712119.2016 .1251927

Akrami, R., Chitsaz, H., Hezarjaribi, A., \& Ziaei, R. (2012). Effect of Dietary MannanOligosaccharide (MOS) on Growth Performance and Immune Response of Gibel Carp Juveniles (Carassius auratus gibelio). Journal of Veterinary Advances, 2(10), 507-513.

Akrami, R., Razeghi Mansour, M., Ghobadi, S., Ahmadifar, E., Shaker Khoshroudi, M., \& Moghimi Haji, M. S. (2013). Effect of prebiotic mannan oligosaccharide on hematological and blood serum biochemical parameters of cultured juvenile great sturgeon (Huso huso L innaeus, 1754). Journal of Applied Ichthyology, 29(6), 1214-1218. https://doi.org/10.1111/jai.12245

Akter, M. N., Hashim, R., Sutriana, A., Siti Azizah, M. N., \& Asaduzzaman, M. (2019). Effect of Lactobacillus acidophilus supplementation on growth performances, digestive enzyme activities and gut histomorphology of striped catfish (Pangasianodon hypophthalmus Sauvage, 1878) juveniles. Aquaculture Research, 50(3), 786-797. https://doi.org/10.1111/are.13938

Ali, S. R., Ambasankar, K., Praveena, E., Nandakumar, S., \& Syamadayal, J. (2017). Effect of dietary mannan oligosaccharide on growth, body composition, haematology and biochemical parameters of Asian seabass (Lates calcarifer). Aquaculture Research, 48(3), 899-908. https://doi.org/10.1111/are.12933

Ali, M. Z., \& Jauncey, K. (2005). Approaches to optimizing dietary protein to energy ratio for African Catfish $C$. gariepinus (Burchell, 1822). Aquaculture Nutrition, 11(2), 95-101. https://doi.org/10.1111/j.13652095.2004.00325.x

Andrews, S. R., Sahu, N. P., Pal, A. K., \& Kumar, S. (2009). Haematological modulation and growth of Labeo rohita fingerlings: effect of dietary mannan oligosaccharide, yeast extract, protein hydrolysate and chlorella. Aquaculture Research, 41(1), 61-69. https://doi.org/10.1111/j.1365-2109.2009.02304.x

AOAC. (1997). Association of Official Analytical Chemists. Official Methods of Analysis of AOAC International, 16th edn, Vol. 1, Arlington, VA, USA, pp 1-3.

Blaxhall, P. C. (1972). The haematological assessment of the health of freshwater fish. Journal of Fish Biology, 4(4), 593-604. https://doi.org/10.1111/j.1095-8649.1972.tb05704.x

Cataldi, E., Di Marco, P., Mandich, A., \& Cataudella, S. (1998). Serum parameters of Adriatic sturgeon Acipenser naccarii (Pisces: Acipenseriformes): effects of temperature and stress. Comparative Biochemistry \& Physiology Part A, 121(4), 351-354.

Denev, S., Beev, G., Staykov, Y., \& Moutafchieva, R. (2009). Microbial ecology of the gastrointestinal tract of fish and the potential application of probiotics and prebiotics in finfish aquaculture. International Aquatic Research, 1(1), 1-29. https://doi.org/10.1111/j.17497345.2005.tb00390.x

Denji, K. A., Mansour, M. R., Akrami, R., Ghobadi, S., Jafarpour, S. A., \& Mirbeygi, S. K. (2015). Effect of dietary prebiotic 
mannan oligosaccharide (MOS) on growth performance, intestinal microflora, body composition, haematological and blood serum biochemical parameters of rainbow trout (Oncorhynchus mykiss) juveniles. Journal of Fisheries and Aquatic Science, 10(4), 255.

Dimitroglo, A., Reynolds, P., Ravnoy, B., Johnsen, F., Sweetman, J. W., Johansen, J. \& Davies, S. J. (2011). The effect of mannan oligosaccharide supplementation on Atlantic salmon smolts (S. salar L.) fed diets with high levels of plant proteins. Journal of Aquaculture Research and Development, S1, 011, https://doi.org/10.4172/2155-9546.S1-011

Dimitroglou, A., Merrifield, D. L., Spring, P., Sweetman, J., Moate, R., \& Davies, S. J. (2010). Effects of mannan oligosaccharide (MOS) supplementation on growth performance, feed utilization, intestinal histology and gut microbiota of gilthead sea bream (S. aurata). Aquaculture, 300, 182-188. https://doi.org/10.1016/j. aquaculture. 2010.01.015

Dimitroglou, A., Merrifield, D. L., Moate, R., Davies, S. J., Spring, P., Sweetman. J., \& Bradley, G. (2009). Dietary mannan oligosaccharide supplementation modulates intestinal microbial ecology and improves gut morphology of rainbow trout, O. mykiss (Walbaum). Journal of Animal Science, 87, 3226-3234. https://doi.org/10.2527/jas.2008-1428

Do Huu, H., \& Jones, C. M. (2014). Effects of dietary mannan oligosaccharide supplementation on juvenile spiny lobster Panulirus homarus (Palinuridae). Aquaculture, 432, 258-264.

https://doi.org/10.1016/j.aquaculture.2014.05.013

Duncan, D. B. (1955). Multiple range and multiple (F) tests. Biometrics, 11(1), 1-42.

Folch, J., Lees, M. \& Solane Stanley, G.H. (1957). A simple method for the isolation and purification of total lipids from animal tissues. Journal of Biological Chemistry, 226 (1), 497-509.

Gelibolu, S., Yanar, Y., Genç, M. A., \& Genç, E. (2018). The effect of mannan-oligosaccharide (MOS) as a feed supplement on growth and some blood parameters of Gilthead Sea Bream (Sparus aurata). Turkish Journal of Fisheries and Aquatic Sciences, 18, 817-823. OI: 10.4194/1303-2712-v18_6_08

Genc, M. A., Aktas, M., Genc, E., \& Yilmaz, E. (2007). Effects of dietary mannan oligosaccharide on growth, body composition and hepatopancreas histology of Penaeus semisulcatus (de Haan 1844). Aquaculture Nutrition, 13, 156-161.

https://doi.org/10.1111/j.1365-2095.2007.00469.x

Gibson, G. R., \& Roberfroid, M. B. (1995). Dietary modulation of the human colonic microbiota: introducing the concept of prebiotics. Journal of Nutrition, 125(6), 14011412. https://doi.org/10.1093/jn/125.6.1401

Grisdale-Helland, B., Helland, S. J., \& Gatlin, D. M. (2008). The effects of dietary supplementation with manna oligosaccharide, fructooligosaccharide or galactooligosaccharide on the growth and feed utilization of Atlantic salmon (S. salar). Aquaculture, 283(1-4), 163-167. https://doi.org/10.1016/j. aquaculture. 2008.07.012

Gultepe, N., Salnur, S., Hossu, B. \& Hisar, O. (2011). Dietary supplementation with Mannan oligosaccharides (MOS) from Bio-Mos enhances growth parameters and digestive capacity of gilthead sea bream (S. aurata).
Aquaculture Nutrition, 17(5), 482-487. https://doi.org/10.1111/j.1365-2095.2010.00824.x

Irianto, A., \& Austin, B. (2002). Probiotics in aquaculture. Journal of Fish Diseases, 25, 633$642 . \quad$ https://doi.org/10.1046/j.13652761.2002.00422.x

Lim, C., Klesius, P. H., Li, M. H., \& Robinson, E. H. (2000). Interaction between dietary levels of iron and vitamin $C$ on growth, hematology, immune response and resistance of channel catfish (Ictalurus punctatus) to Edwardsiella ictaluri challenge. Aquaculture, 185(3-4), 313-327. 8486(99)00352-X

Mansour, M. R., Akrami, R., Ghobadi, S. H., Denji, K. A., Ezatrahimi, N., \& Gharaei, A. (2012). Effect of dietary mannan oligosaccharide (MOS) on growth performance, survival, body composition, and some hematological parameters in giant sturgeon juvenile $(H$. huso Linnaeus, 1754). Journal Fish Physiology and Biochemistry, 38(3), 829-835. https://doi.org/10.1007/s10695-011-9570-4

Mazlum, Y., Yilmaz, E., Genc, M. A., \& Guner, O. (2011). A preliminary study on the use of mannan oligosaccharides (MOS) in fresh water crayfish, Astacus leptodactylus Eschscholtz, 1823 juvenile diets. Aquaculture International, 19,111-119. https://doi.org/10.1007/s10499-010-9345-4

Merrifield, D. L., Dimitroglou, A., Foey, A., Davies, S. J., Baker, R. T. M., Bogwald, J., Castex M., \& Ringo, E. (2010). The current status and future focus of probiotic and prebiotic applications for salmonids. Aquaculture, 302(1-2), 1-18. https://doi.org/10.1016/j.aquaculture.2010.02.007

Newman, K. (1994). Mannan-oligosaccharides: Natural polymers with significant impact on the gastrointestinal microflora and the immune system. Biotechnology in the Feed Industry. 10, 167-174.

Peterson, B. C., Booth, N. J., Barrows, F. T., \& Manning, B. B. (2012). Improved survival in channel catfish fed mannanoligosaccharides in an extruded diet. Open Journal of Animal Sciences, 2(2), 57-61. http://dx.doi.org/10.4236/ojas.2012.22009

Phumee, P. (2011). Optimal protein-lipid level and replacement of fish meal with plant protein sources in feeds formulated for $P$. hypophthalmus, Sauvage, 1878. PhD Thesis. Universiti Sains Malaysia, Malaysia.

Pryor, G. S., Royes, J. B., Chapman, F. A., \& Miles, R. D. (2003). Mannan oligosaccharides in fish nutrition: Effects of dietary supplementation on growth and gastrointestinal villi structure in Gulf of Mexico sturgeon. North American Journal of Aquaculture, 65(2), 106-111. https://doi.org/10.1577/1548-8454(2003)65<106: MIFNEO >2.0.CO;2

Reza, A., Abdolmajid, H., Abbas, M., \& Abdolmohammad, A. K. (2009). Effect of dietary prebiotic inulin on growth performance, intestinal microflora, body composition and hematological parameters of juvenile Beluga, Huso huso (Linnaeus, 1758). Journal of the World Aquaculture Society, 40(6), 771-779. https://doi.org/10.1111/j.17497345.2009.00297.x

Ringo, E., Olsen, R. E., Gifstad, T. O., Dalmo, R. A., Amlund, H., Hemre, G. I., \& Bakke, A. M. (2010). Prebiotics in aquaculture: a review. Aquaculture Nutrition, 16(2), 117-136. https://doi.org/10.1111/j.13652095.2009.00731.x 
Roberts, R. J. (1978). The pathophysiology and systemic pathology of teleosts. In: Roberts, R. J. (ed), Fish Pathology. Bailliere Tindal, London, UK, pp. 55-91.

Rosa, R., Bandarra, N. M., \& Nunes, M. L. (2007). Nutritional quality of African Catfish C. gariepinus (Burchell 1822): a positive criterion for the future development of the European production of Siluroidei. International Journal of Food Science and Technology, 42 (3), 342 - 351. https://doi.org/10.1111/j.1365-2621.2006.01256.x

Sado, R. Y., Bicudo, A. J. D. A., \& Cyrino, J. E. P. (2008). Feeding dietary mannan oligosaccharides to juvenile Nile tilapia (O. niloticus), has no effect on hematological parameters and showed decreased feed consumption. Journal of the World Aquaculture Society, 39 (6): 821-826. https://doi.org/10.1111/j.1749-7345.2008.00219.x

Salaghi, Z., Imanpuor, M., \& Taghizadeh, V. (2013). Effect of Different Levels of Probiotic Primalac on Growth Performance and Survival Rate of Persian Sturgeon Acipenser persicus. Global Veterinaria, 11(2), 238-242. https://doi.org/10.5829 /idosi.gv. 2013. 11.2.7545

Samrongpan, C., Areechon, N., Yoonpundhan, R., \& Srisapoome, P. (2008). Effects of mannan oligosaccharide on growth, survival and disease resistance of Nile tilapia (Oreochromis niloticus Linnaeus) fry. 8th International Symposium on Tilapia in Aquaculture, 345-353.

Sang, H. M., \& Fotedar, R. (2010). Effects of mannan oligosaccharide dietary supplementation on performances of the tropical spiny lobsters juvenile (Panulirus ornatus, Fabricius 1798). Fish \& Shellfish Immunology, $\quad 28 \quad$ (3), 483-489. https://doi.org/10.1016/j.fsi.2009.12.011

Staykov, Y., Spring, P., Denev, S., \& Sweetman, J. (2007). Effect of mannan oligosaccharide on the growth performance and immune status of rainbow trout (O. mykiss). Aquaculture International, 15(2), 153-161.

Taati, R., Soltani, M., Bahmani, M., \& Zamini, A. A. (2011). Growth performance, carcass composition and immune- physiological indices in juvenile great sturgeon (Huso huso) fed on commercial prebiotic, Immunoster. Iranian Journal of Fisheries Sciences, 10(2), 324-335.

Torrecillas, S., Makol, A., Caballero, M.J., Montero, D., Gines, R., Sweetman, J., \& Izquierdo, M. (2011). Improved feed utilization, intestinal mucus production and immune parameters in sea bass (Dicentrarchus labrax) fed mannan oligosaccharide (MOS). Aquaculture Nutrition, 17 (2), 223-233. https://doi.org/10.1111/j.13652095.2009.00730.x

Torrecillas, S., Makol, A., Caballero, M. J., Montero, D., Robaina, L., Real, F., Sweetman, J., Tort, L., \& Izquierdo, M. S. (2007). Immune stimulation and improved infection resistance in European sea bass (Dicentrarchus labrax) fed mannan oligosaccharides. Fish \& Shellfish Immunology, 23(5), 969-981.

Verschuere, L., Rombaut, G., Sorgeloos, P., \&Verstraete, W. (2000). Probiotic bacteria as biological control agents in aquaculture. Microbiology and Molecular Biology Reviews, 64 (4), 655-671. https://doi.org/10.1128/mmbr.64.4.655-671.2000

Welker, T. L., Lim, C., Yildirim-Aksoy, M., Shelby, R., \& Klesius, P. H. (2007). Immune response and resistance to stress and Edwardsiella ictaluri challenge in channel catfish, Ictalurus puncatus, fed diets containing commercial whole-cell yeast or yeast subcomponents. Journal of the World Aquaculture Society, 38 (1), 24-35. https://doi.org/10.1111/j.1749-7345.2006.00070.x

Wu, Z. X., Yu, Y. M., Chen, X., Liu, H., Yuan, J. F., Shi, Y., \& Chen, X. X. (2014). Effect of prebiotic konjac mannan oligosaccharide on growth performances, intestinal micro flora, and digestive enzyme activities in yellow catfish, Pelteobagrus fulvidraco. Fish Physiology and Biochemistry, 40, 763-771. https://doi.org/10.1007/s10695-013-9883-6

Yousefian, M., \& Amiri, M. S. (2009). A review of the use of prebiotic in aquaculture for fish and shrimp. African Journal of Biotechnology, 8 (25), 7313-7318. 